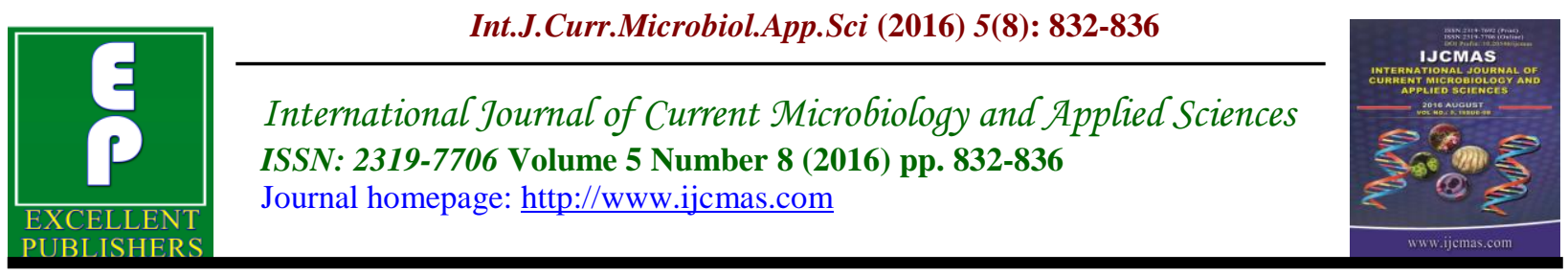

Original Research Article

http://dx.doi.org/10.20546/ijcmas.2016.508.093

\title{
Bacteriological Profile of Burn Patients in a Tertiary Care Hospital, Jamnagar, Gujarat, India
}

\author{
Pooja A. Kamaria*, Binita J. Aring and Mala Sinha \\ Department of Microbiology, Shri M. P. Shah Government Medical College and \\ GGG Hospital, Jamnagar, Gujarat, India \\ *Corresponding author
}

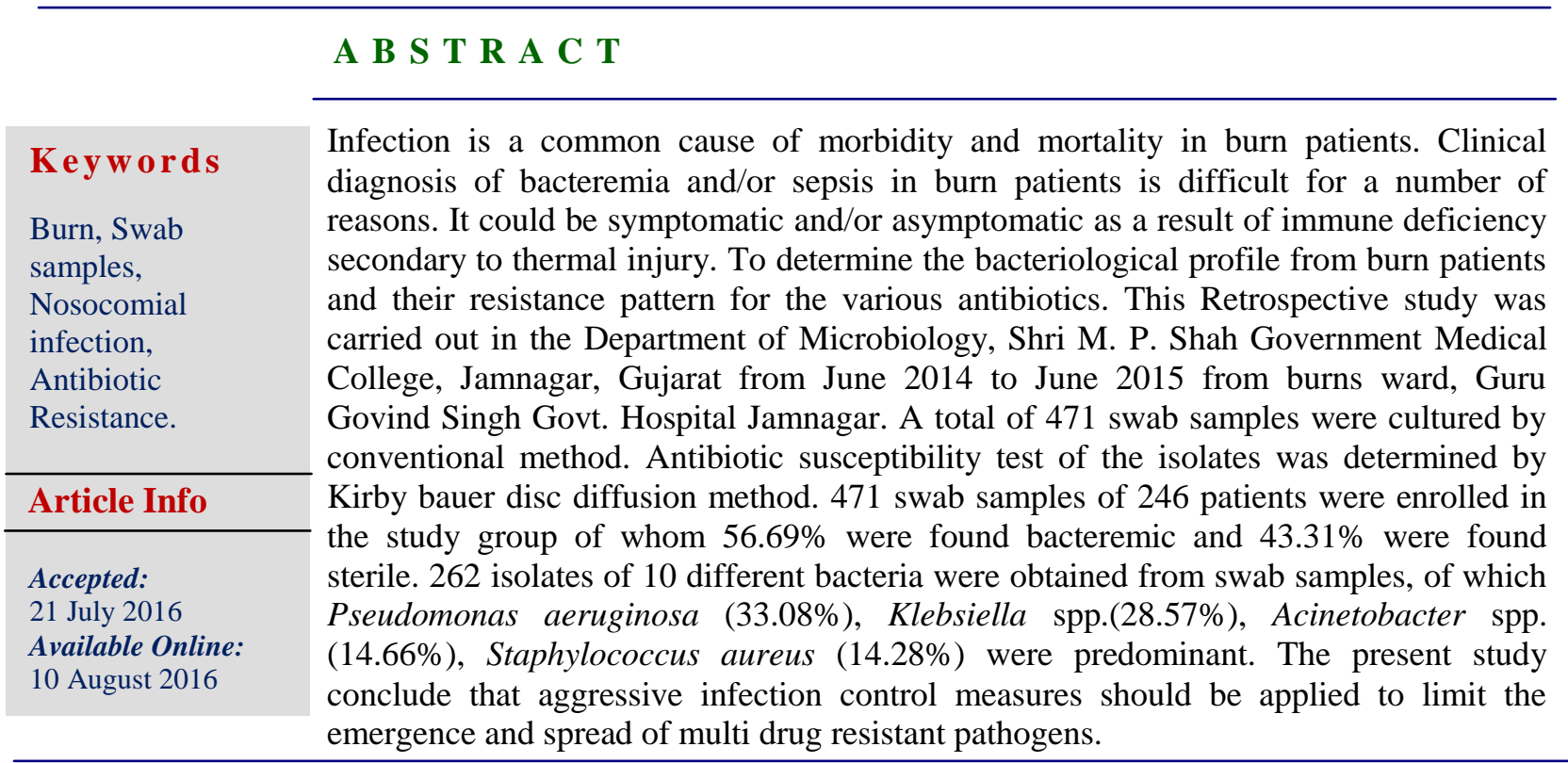

\section{Introduction}

Burn wound infection is one of the most co mmon causes of mortality and morbidity in burn patients (Sedat et al., 2005). It has been estimated that $75 \%$ of all deaths following thermal injuries are related to infections (Vindenes et al., 1995). The rate of nosocomial infections are higher in burn patients due to various factors like nature of burn injury itself, immunocompromised status of the patient, invasive diagnostic and therapeutic procedures and prolonged ICU stay (Pruitt et al., 1998).

Initially, the burnt area is considered free of microbial contamination. But gram-positive bacteriain the depth of sweat glands and hair follicles heavily colonized the wound within 48 hours of the injury (Luterman; Mooney, 1989). Topical antimicrobials decrease microbial overgrowth but seldom prevent further colonization with other potentially invasive bacteria. These are derived from patient's gastrointestinal and upper respiratory tract and the hospital environment (Monafo et al., 1987; Hansbrough, 1987). Following colonization, these organisms start penetrating the viable tissue depending on their invasive capacity, local wound factors and degree of the 
patient's immunosuppression (Hansbrough et al., 1987).

The causative infective microorganisms in any burn facility change with time. Individual organisms are brought into burns ward on the wounds of new patients. These organisms persist in the resident flora of the burn treatment facility for a variable period of time, only to be replaced by newly arriving microorganisms. Introduction of new topical agents and systemic antibiotics influence the flora of the wound (Pruitt et al., 1984; Manson et al., 1992).

The importance of preventing infection has been recognized in organized burn care centers starting from its inspection. These include strict aseptic techniques, use of sterile gloves and dressing materials, wearing mask for dressing changes and special separation of patients, using private rooms (Sharma, 2005).

\section{Materials and Methods}

This retrospective study was carried out in the Department of Microbiology, Shree M.P. Shah Govt. Medical College and G.G.G. Hospital, Jamnagar, Gujarat from June 2014 to June 2015. We have included pus swab samples and excluded other samples like blood, urine, stool and other body fluids. A total of 471 pus swab samples were received from burns ward of Guru Gobind Singh Govt. Hospital, Jamnagar.

All the samples were inoculated on MacConkey agar, Blood agar and Nutrient agar plates. The culture plates were incubated aerobically for $24 \mathrm{hrs}$ at $37^{\circ} \mathrm{C}$. Growth and cultural characteristics were observed next day. Bacterial pathogens were identified by conventional biochemical methods according to standard microbiological techniques. Anti-microbial sensitivity testing was done according to the CLSI (Clinical and Laboratory Standards Institute) guidelines (CLSI, 2014) by Kirby bauer disc diffusion method for Amikacin (30mcg), Netilmycin(30mcg), Gentamycin (10mcg), Ceftazidime(30mcg), Piperacillin+ Tazobactum (100mcg/10mcg), Aztreonem (30mcg), Imipenem (10mcg), Ciprofloxacin (5mcg), Azythromycin(30 mcg), Linezolid (30 mcg) and Vancomycin $(30 \mathrm{mcg})$.

\section{Ethical clearance}

It is a retrospective analysis of samples tested for routine laboratory diagnosis; hence ethical clearance is not necessary.

\section{Statistics}

Data was entered and analyzed in MS excel 2007.

\section{Results and Discussion}

In the present study, bacterial isolates were found in 267 (56.69\%) swab samples \& 171 $(43.31 \%)$ were found sterile. Table -1 shows that $43(16.41 \%)$ isolates were gram positive organisms and $219(83.59 \%)$ were gram negative organisms. Table-2 shows that Pseudomonas aeruginosa was the commonest pathogen isolated (33.59\%). Other isolates include Klebsiella spp. (29.01\%), Acinetobacter spp. (14.89\%), Staphylococcus aureus (14.50\%), E.coli (3.44\%), Proteus spp. (2.66\%) and Enterococcus spp. (1.91\%).

The Susceptibility of the organisms to different antibiotics varied depending on the isolates. Table-3 shows Antibiotic Resistant pattern of Gram negative bacilli. Pseudomonas aeruginosa was highly resistant to Gentamicin (89.77\%) and least resistant to Imipenem (15.90\%). Acinetobacter spp. was highly resistant to 
Ceftazidime (93.54\%) and least resistant to Imipenem (48.71\%). Resistant to Gentamicin (86.84\%) and Ceftazidime $(86.84 \%)$ were high for the Klebsiella spp. Other gram negative bacilli were least resistant to imipenem (50.00\%). $P$. aeruginosa and Acinetobacter spp. were found to be Multidrug resistant. 33 (37.5\%) isolates of $P$. aeruginosa and $25(64.10 \%)$ isolates of Acinetobacter spp. were multidrug resistant.

Table-4 Resistant pattern of Gram positive cocci. S aureus and Enterococci spp. show $0 \%$ resistant to both for Vancomycin and Linezolid.

Table.1 No. of gram positive and gram negative organisms isolated

\begin{tabular}{|c|c|c|}
\hline Type of Organisms & No. of strains & Percentage \\
\hline $\begin{array}{c}\text { Gram Positive } \\
\text { Organisms }\end{array}$ & 43 & $16.41 \%$ \\
\hline $\begin{array}{c}\text { Gram Negative } \\
\text { Organisms }\end{array}$ & 219 & $83.59 \%$ \\
\hline
\end{tabular}

Table.2 Various isolate recovered from burns patients

\begin{tabular}{|c|c|c|}
\hline Organism & $\begin{array}{c}\text { No. (out of 262 } \\
\text { isolates) }\end{array}$ & Percentage (\%) \\
\hline Pseudomonas aeruginosa & 88 & 33.59 \\
\hline Klebsiella spp. & 76 & 29.01 \\
\hline Acinetobacter spp. & 39 & 14.89 \\
\hline Staphylococcus aureus & 38 & 14.50 \\
\hline Escherichia coli & 9 & 3.44 \\
\hline Proteus spp. & 7 & 2.66 \\
\hline Enterococcus spp. & 5 & 1.91 \\
\hline
\end{tabular}

Table.3 Antibiotic resistant pattern of gram negative organisms

\begin{tabular}{|l|c|c|c|c|}
\hline \multicolumn{1}{|c|}{$\begin{array}{c}\text { Name of } \\
\text { antibiotics }\end{array}$} & $\begin{array}{c}\text { P.aeruginosa } \\
\mathbf{N = 8 8}\end{array}$ & $\begin{array}{c}\text { Acinetobacter } \\
\text { spp. } \\
\mathbf{N = 3 9}\end{array}$ & $\begin{array}{c}\text { Klebsiella spp. } \\
\mathbf{N = \mathbf { 7 6 }}\end{array}$ & $\begin{array}{c}\text { Other Gram Negative } \\
\text { Microorganisms } \\
\text { N= 16 } \\
\text { Resistance (\%) }\end{array}$ \\
Resistance (\%) & Resistance (\%) & Resistance (\%) \\
\hline Ceftazidime (CAZ) & $68(77.27 \%)$ & $29(93.54 \%)$ & $66(86.84 \%)$ & $10(62.5 \%)$ \\
\hline $\begin{array}{l}\text { Piperacillin+ } \\
\text { Tazobactum(PT) }\end{array}$ & $48(54.54 \%)$ & $30(76.92 \%)$ & $49(64.47 \%)$ & $9(56.25 \%)$ \\
\hline Imipenem (IMP) & $14(15.90 \%)$ & $19(48.71 \%)$ & $51(67.10 \%)$ & $8((50.00 \%)$ \\
\hline Gentamicin (GEN) & $79(89.77 \%)$ & $31(79.48 \%)$ & $66(86.84 \%)$ & $14(87.5 \%)$ \\
\hline Ciprofloxacin (CIP) & $76(86.36 \%)$ & $33(84.61 \%)$ & $65(85.52 \%)$ & $15(93.75 \%)$ \\
\hline Netilmicin (NET) & $66(75.00 \%)$ & $20(51.28 \%)$ & $55(72.36 \%)$ & $11(68.75 \%)$ \\
\hline Colistin (CL) & $0(0 \%)$ & $0(0 \%)$ & NT & NT \\
\hline
\end{tabular}

$(* \mathrm{NT}=$ Not Tested $)$ 
Table.4 Antibiotic resistant pattern of gram positive organisms

\begin{tabular}{|c|c|c|}
\hline $\begin{array}{c}\text { Name of } \\
\text { antibiotics }\end{array}$ & $\begin{array}{c}\text { S. aureus } \\
(\mathbf{N}=\mathbf{3 8}) \\
\text { Resistance (\%) }\end{array}$ & $\begin{array}{c}\text { Enterococcus } \mathbf{s p p} \text {. } \\
(\mathbf{N}=\mathbf{5}) \\
\text { Resistance (\%) }\end{array}$ \\
\hline Erythromycin & 47.37 & 80 \\
\hline Clindamicin & 26.31 & NT \\
\hline Linezolid & 0 & 0 \\
\hline Vancomycin & 0 & 0 \\
\hline Ciprofloxacin & 42.10 & 80 \\
\hline Ampicillin & 94.28 & 100 \\
\hline \multicolumn{2}{|c|}{ (*NT = Not Tested) }
\end{tabular}

In the present study, the most commonly isolated organism from burn patients was Pseudomonas aeruginosa, followed by Klebsiella spp., Acinetobacter spp. and S. aureus were predominant. A study done by Manjula et al., (2007) shows that most commonly isolated organism was Pseudomonas aeruginosa (51.5\%) followed by Acinetobacter spp. (14.28\%), S. aureus $(11.15 \%)$, Klebsiella spp. (9.23\%) were predominant. Other study done by Ganesamoni S. et al., (2010) also shows that commonest organism was P.aeruginosa (81.1\%), followed by Acinetobacter spp. and S. aureus.

The bacterial resistance pattern is important for clinical and epidemiological purpose. A comparative study done by Indu et al., (2014) shows that P.aeruginosa was $81.03 \%$ and $18.9 \%$ resistant to Gentamicin and Imipenem respectively. A study done by Yasemin et al., (2013) shows that for Acinetobacter spp., resistance to Ceftazidime, Gentamicin, Ciprofloxacin and Imipenem were $93 \%, 86 \%, 86 \%$ and $86 \%$ respectively. For vancomycin and linezolid resistance, comparative done by Yasemi et al., (2013) shows 0\% resistance for both the drugs, which are comparable to present study.
The main limitations of present study are retrospective study design and collection of data from a single burn centre. There is also unavailability of culture isolates for molecular analysis or additional testing to determine if isolates were acquired through nosocomial transmission. It is also known that widespread use of broad spectrum antimicrobials in burn units may lead to acquisition of resistance and transformation to form new strains (Chim et al., 2007).

The present study conclude that isolation of multidrug resistant should be considered as a serious risk in burn units. Routine microbiological surveillance and careful invitro testing prior to antibiotic use and strict adherence to hospital policy.

\section{References}

Chim, H., Tan, B.H., Song, C. 2007. Fiveyear review of infections in a burn intensive care unit: High incidence of Acinetobacter baumannii in a tropical climate. Burns. 2007;33(8):1008-14.

CLSI. 2014. Performance Standards for Antimicrobial Susceptibility Testing; Twenty-Fourth Informational Supplement. CLSI document M100S24. Wayne, PA: Clinical and Laboratory Standards Institute. 
Ganesamoni, S., Kate, V., Sadasivan, J.Epid emiology of hospitalized burn patients in a tertiary care hospital in South Indi a.NCBI. 36(3): 422-9. (PubMed)

Hansbrough, J.F. 1987.Burn wound sepsis. J. Intensive Care Med., 2: 313-27.

Indu, B. 2014. Incidence of multidrug resistant Pseudomonas aeruginosa isolated from burn patients and environment of teaching institute. PMCID: PMC4080000.

Luterman, A., Dasco, C.C., Curreri, P.W. 19 86.Infection in burn patients. Am. J. M ed., 81: 45-52. (PubMed)

Manjula, M., Priya, D., Varsha, G. 2007. Bacterial isolates from burn wound infections and their antibiograms: A eight-year study. Indian J. Plastic Surgery, 40(1): 25-28.

Manson, W.L., Pernot, P.C., Fidler, V., Saue r, E.W. 1992. Colonisation of burns and duration of hospital stay of severel y burned patients. J. Hosp. Infect.,22: $55-63$.

Monafo, W.W., Freedman, B. 1987.Tropical therapy for burns. Surg. Clin. North A m., 67: 133-45.

Mooney, D.P., Gamelli, R. L. 1989. Sepsis following thermal injury. CompTher., 15: 22-9. (PubMed)
Pruitt, Jr. B.A., McManus, A.T., Kim, S.H., Goodwin, C.W. 1998. Burn Wound infections: current status. World $J$. Surg., 22: 135-45.

Pruitt, B.A., Jr, McManus, A.T. 1984.Oppu rtounistic infections in severely burnt patients. Am. J. Med., $\quad 76: \quad 146-$ 54. (PubMed)

Sedat, Y., Tarik, Z., Nurkan, T., Targut, N., Yusuf, Z., Gokhan, M., Mehmet, H. 2 005.Bacteriological profile and antibio tic resistance. J. Burnwound and Reha bilitation, 6(6): 488. (PubMed)

Sharma, B.R., Virendar, P., Sumedha, B., N eha,G. 2005.Septicemia the principal $\mathrm{k}$ iller of burn patients. Amer. J. Infect. Dis., 1(3): 132-138.

Vindenes, H., Bjerknes, R. 1995. Microbial colonization of large wounds. Burns, 21: 575-9.

Yasemin, Bayram, Mehmet Parlak, Cenk Aypak, İrfan Bayram. 2013. Threeyear Review of Bacteriological Profile and Antibiogram of Burn Wound Isolates in Van, Turkey. IJMS, 10(1): 19-23.

\section{How to cite this article:}

Pooja A. Kamaria, Binita J. Aring and Mala Sinha. 2016. Bacteriological Profile of Burn Patients in a Tertiary Care Hospital, Jamnagar, Gujarat, India. Int.J.Curr.Microbiol.App.Sci. 5(8): 832-836. doi: http://dx.doi.org/10.20546/ijcmas.2016.508.093 